Laporan Penelitian

\title{
Pengaruh kemoterapi neoadjuvant terhadap ekspresi NFkB dan c-myc pada karsinoma nasofaring jenis undifferentiated
}

\author{
Farida Nurhayati *, Muhardjo *, Made Setiamika *, Dyah Ratna Budiani** \\ * SMF IK THT-KL Fakultas Kedokteran Universitas Sebelas Maret Surakarta \\ Rumah Sakit Dr. Moewardi Surakarta \\ ** SMF Patologi Anatomi Fakultas Kedokteran Universitas Sebelas Maret Surakarta
}

\begin{abstract}
ABSTRAK
Latar belakang: Patogenesis Karsinoma Nasofaring (KNF) banyak dikaitkan dengan infeksi virus Epstein Barr. Virus ini menyebabkan jaringan mengekspresikan Nuclear Factor Kappa Beta (NFkB). NFkB dan c-myc merupakan faktor transkripsi, yang menyebabkan proliferasi jaringan. Adanya ekspresi NFkB dan c-myc merupakan dua faktor penting sebagai penanda terjadinya keganasan. Pemberian kemoterapi neoadjuvant diharapkan dapat menghambat proses proliferasi dan menyebabkan terjadinya apoptosis. Tujuan: Mengetahui pengaruh kemoterapi neoadjuvant terhadap ekspresi NFKB dan c-myc pada KNF jenis undifferentiated dan hubungan antara ekspresi NFkB dan c-myc. Metode dan bahan penelitian: Penelitian eksperimen kuasi dengan rancangan one group before and after intervention. Sebanyak 10 sampel dari jaringan biopsi KNF jenis undifferentiated, masing-masing dilakukan pemeriksaan ekspresi NFkB dan c-myc sebelum dan sesudah pengobatan. Analisa dengan Uji statistk Wilcoxon signed Ranks test dan Spearman's menggunakan SPSS 15.0 program underwindow. Hasil penelitian: Setelah kemoterapi neoadjuvant terjadi peningkatan signifikan $(\mathrm{p}=0,005)$ ekspresi $\mathrm{NF} \kappa \mathrm{B}(1,11 \pm 1,14$ dibanding $4,92 \pm 2,79)$ dan terjadi peningkatan signifikan ( $\mathrm{p}=0.025)$ ekspresi $\mathrm{c}-$ myc $(1,15 \pm 0,78$ dibanding $3,04 \pm$ 1,91). Analisis hubungan antara ekspresi NFKB dengan c-myc pada KNF jenis undifferentiated memenuhi garis liniar dan signifikan $(\mathrm{p}=0,001)$. Kesimpulan: Terdapat peningkatan ekspresi NFkB dan c-myc sesudah kemoterapi neoadjuvant yang signifikan pada KNF jenis undifferentiated. Terdapat hubungan signifikan antara ekspresi NFKB dengan c-myc pada KNF jenis undifferentiated.
\end{abstract}

Kata kunci: karsinoma nasofaring, kemoterapi neoadjuvant, $N F \kappa B$ dan $c-m y c$

\section{ABSTRACT}

Background: Epstein Barr, virus (EBV) infection has been frequently related with Nasopharyngeal Carcinoma (NPC), this virus makes the tissue of nasopharyng express Nuclear Factor Kappa Beta $(N F \kappa B) . N F \kappa B$ and c-myc are two transcriptional factor for proliferation. $N F \kappa B$ and c-myc are two sign system for malignancy. The administration of neoadjuvant chemotherapy may prevent the apoptosis and inhibit the proliferation. Purpose: To evaluate the effect of neoadjuvant chemotherapy upon the expression level of NFKB and c-myc in undifferentiated NPC. Method: Quasi Experimental research by one group before and after intervention design. Ten sampels were collected from nasopharyngeal biopsy tissue which had been diagnosed as undifferentiated NPC. Wilcoxon signed Ranks test and Spearman's were used to analized data, utilizing SPSS 15.0 underwindows program. Result: After neoadjuvant chemotherapy, there were significant increase $(p=0.005)$ for expression of $N F \kappa B(1.11 \pm 1.14 / 4.92 \pm 2.79)$ and significant increase for expression of c-myc $(1.15 \pm 0,78 / 3.04 \pm 1.91)$. There were significant corelation between expresion of $N F \kappa B$ and $c-m y c$ in undifferentiated NPC $(p=0.001)$. Conclussion: There were significant increase in expression of $N F \kappa B$ and c-myc after neoadjuvant chemotherapy in undifferentiated NPC, and significant corelation between expresion of $N F \kappa B$ and c-myc in undifferentiated NPC. 
Keywords: nasopharyngeal carcinoma, neoadjuvant chemotherapy, $N F \kappa B$ and c-myc

\section{Alamat korespondensi: Farida Nurhayati. Email: dr.faridha@yahoo.co.id HP 08127911223}

\section{PENDAHULUAN}

Di Indonesia prevalensi karsinoma nasofaring (KNF) berada di peringkat kelima dari semua keganasan pada tubuh manusia, angkanya mencapai 6 diantara 100.000 penduduk pertahun. ${ }^{1,2}$

Berbagai penelitian akhir-akhir ini telah membuktikan Epstein Barr Virus (EBV) selalu ditemukan pada biopsi KNF. ${ }^{3-5}$ Gambaran histopatologi terbanyak adalah jenis undifferentiated, sebesar $86 \%$ dan karsinoma sel skuamosa berkeratin $14 \%{ }^{1-5}$

Insidens KNF undifferentiated di Amerika Utara sebesar $63 \%$ dan di Cina Selatan $95 \%$, sedangkan di RSUD Moewardi selama tahun 2008-2009 insidens KNF undifferentiated sebesar $89,1 \%{ }^{6}$

Faktor transkripsi yang mempunyai peran penting dalam immortalitas sel adalah Nuclear Factor kappa Beta ( NFkB ) dan c-myc. Ekspresi NFKB berperan dalam regulasi ekspresi gen yang terkait dengan fungsi respons imun dan inflamasi, pertumbuhan dan proliferasi sel, serta pertahanan sel terhadap stress. ${ }^{7-9}$

Ketidak-beresan NFאB telah dikaitkan dengan proses keganasan, inflamasi, penyakit autoimun, syok septik, dan infeksi virus, sehingga menyebabkan immortalisasi sel dan proliferasi sel. Peningkatan ekspresi NFkB akan menyebabkan peningkatan ekspresi c-myc. ${ }^{9}$

$\mathrm{NF} \kappa \mathrm{B}$ merupakan salah satu faktor transkripsi yang menginduksi ekspresi c-myc. Adanya peningkatan ekspresi $\mathrm{NF} \kappa \mathrm{B}$ yang diikuti dengan peningkatan c-myc, IL1, TNF, IL 6 dan Cyclic D1 menandakan terjadinya proses malignansi. ${ }^{7,9}$

Target transkripsi dari EBV yang lain adalah c-myc. Melalui proses dimerisasi dengan Maz, c-myc merupakan faktor transkripsional induk yang meregulasi mekanisme siklus sel. Epstein Barr Nuclear Antigen-2 (EBNA-2) bekerja sebagai suatu regulator positif dari ekspresi c-myc dalam konteks promoter P1-P2 asli setelah infeksi pada sel B yang istirahat. Aktivasi NF $\mathrm{BB}$ oleh Latent Membrane Protein-1 (LMP-1) juga dapat meningkatkan ekspresi c-myc. ${ }^{10}$

Salah satu modalitas terapi yang digunakan untuk karsinoma nasofaring adalah kemoterapi neoadjuvant, yaitu pemberian kemoterapi yang mendahului modalitas terapi lain. Salah satu regimen kemoterapi neoadjuvant yang bisa digunakan adalah Cisplatin dan 5-Fluorouracil (5 FU) yang diikuti dengan radioterapi Cobalt 60. ${ }^{1,2,4,11}$

Cisplatin memiliki mekanisme cross-linking terhadap DNA sehingga mencegah replikasi dengan bekerja pada fase G1 dan G2. Sedangkan 5 FU merupakan anti metabolit yang bekerja dengan cara menghambat sintesa DNA pada fase S. ${ }^{12}$

Radioterapi dengan menggunakan Cobalt 60 dapat menyebabkan kerusakan jaringan akibat terjadinya nekrosis sel. ${ }^{4,12-14}$

Penelitian ini bertujuan untuk mengetahui pengaruh kemoterapi neoadjuvant dengan Cisplatin, 5 FU dan diikuti radiasi Cobalt 60 terhadap ekspresi NFKB dan c-myc dan hubungan antara ekspresi NFkB dan c-myc pada pasien KNF undifferentiated.

\section{METODOLOGI}

Penelitian ini dilakukan pada bulan September 2009 sampai dengan Maret 2011. Tempat penelitian adalah Laboratorium Patologi Anatomi FK UNS Surakarta, Poliklinik THT, Laboratorium Patologi, Ruang Radioterapi dan Bangsal Rawat Inap Anggrek 2 di RSUD Dr Moewardi Surakarta.

Didapatkan data sekunder dari 10 pasien KNF jenis undifferentiated yang dipilih dengan cara yang telah ditentukan dan memenuhi kriteria inklusi.

Sampel berupa biopsi nasofaring pasien KNF jenis ndifferentiated. Pemeriksaan ekspresi 
$\mathrm{NF} \kappa \mathrm{B}$ dan $\quad$ c-myc menggunakan pemeriksan imunohistokimia dengan sistem Avidin Biotin Complex (ABC). Antibodi yang digunakan mouse anti NFkB (Santa Cruz) dan mouse anti c-myc (Santa Cruz). Substrat enzim yang digunakan adalah Diaminobenzidin tetrahidrochloride (DAB).

Rancangan penelitian ini adalah One group before and after intervention yang merupakan penelitian eksperimental semu atau kuasi. ${ }^{15}$

\section{HASIL}

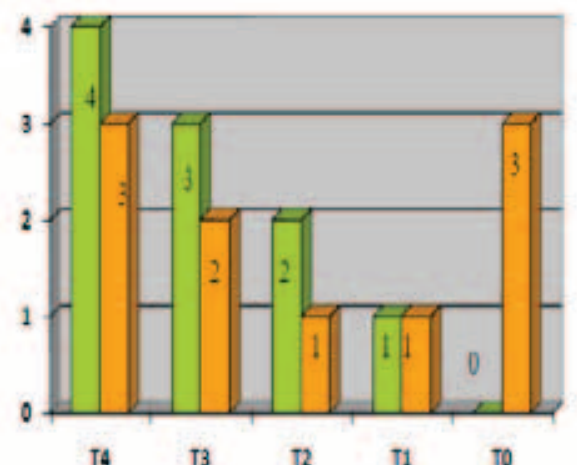

DPRE TERAPI DPOST TERP

Gambar 1. Diagram atang distribusi sampel berdasarkan Staging tumor primer (T) sebelum dan sesudah kemoterapi neoadjuvant.

Dari gambar-1 terlihat adanya perbaikan staging tumor primer setelah pemberian kemoterapi neoadjuvant.
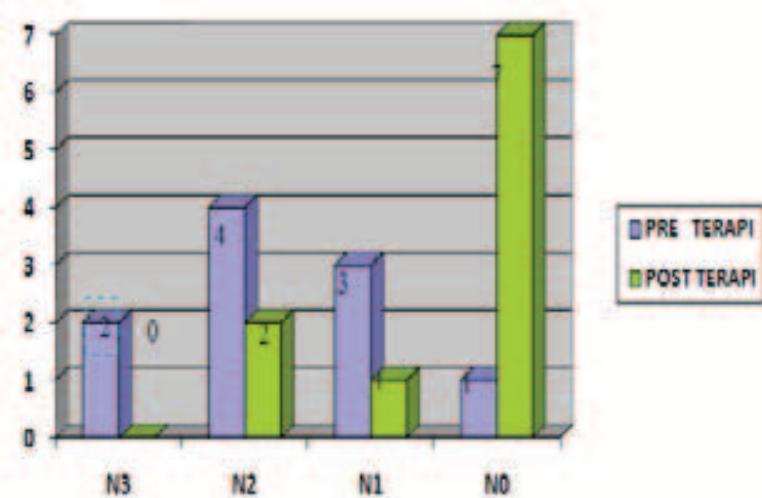

Gambar 2. Diagram Batang distribusi sampel berdasarkan staging nodul $(\mathrm{N})$ sebelum dan sesudah kemoterapi neoadjuvant.

Dari gambar-2 terlihat adanya perbaikan staging nodul setelah pemberian kemoterapi neoadjuvant.
Setelah dilakukan pemeriksaan terhadap seluruh sampel dengan menggunakan mikroskop Olympus seri BX 41, didapatkan 10 data skor histologi $\mathrm{NF} \kappa \mathrm{B}$ dan 10 data skor histologi c-myc sebelum kemoterapi neoadjuvant; serta 10 data skor histologi NFkB dan 10 data skor histologi c-myc sesudah kemoterapi neoadjuvant.

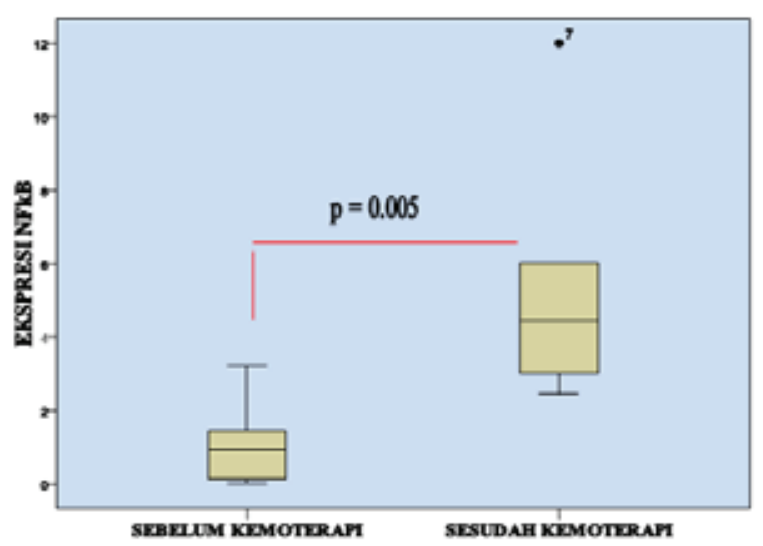

Gambar 3. Boxplot hasil ekspresi NFкB sebelum dan sesudah kemoterapi neoadjuvant pada jaringan KNF undiffere tiated $(\mathrm{p}=0.005)$.

Dari gambar-3 terlihat adanya peningkatan ekspresi NFkB $(1.11 \pm 1.14$ dibanding $4.92 \pm$ 2.79) setelah pemberian kemoterapi neoadjuvant. Peningkatan ini signifikan dengan nilai $\mathrm{p}=0.005$.

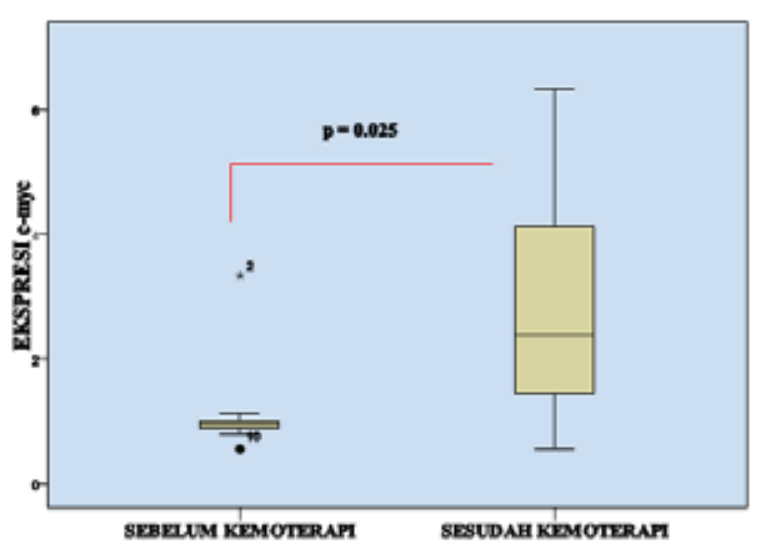

Gambar 4. Boxplot hasil ekspresi c-myc sebelum dan sesudah kemoterapi neoadjuvant pada jaringan KNF Undifferentiated $(\mathrm{p}=0.025)$.

Dari gambar-4 terlihat adanya peningkatan ekspresi c-myc $(1.15 \pm 0.78$ dibanding $3.04 \pm$ 1.91) setelah pemberian kemoterapi neoadjuvant. Peningkatan ini signifikan dengan nilai $\mathrm{p}=$ 0.025 . 


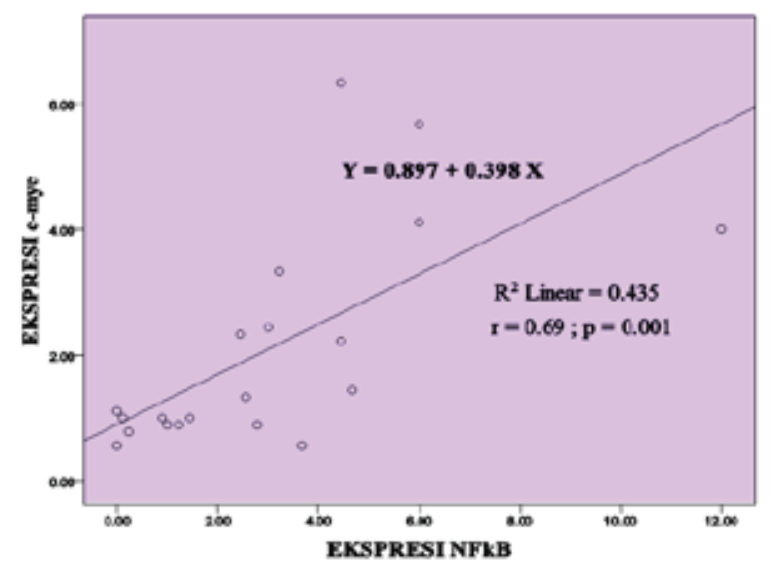

Gambar 5. Hubungan antara ekspresi NFkB dengan c-myc pada KNF jenis Undifferen tiated ( $\mathrm{p}=0.001)$.

Dari gambar-5 dapat dilihat bahwa Ekspresi c-myc akan mengalami peningkatan dengan bertambahnya ekspresi NFkB.

Peningkatan ekspresi c-myc ini signifikan $(\mathrm{p}=0.001)$ dan hubungan ini mampu dijelaskan sebesar $43,5 \%$, selebihnya sebesar $56,5 \%$ peningkatan ekspresi c-myc akibat faktor lain.

\section{DISKUSI}

Adanya perubahan perbaikan staging tumor lokal (T) (gambar 1) dan staging nodul $(\mathrm{N})$ (gambar 2) pada penelitian ini membuktikan bahwa pada KNF jenis undifferentiated dengan pemberian radioterapi dan kemoterapi kombinasi Cisplatin dengan $5 \mathrm{FU}$ mampu menghambat pertumbuhan sel sel tumor lokal maupun lokoregional.

Hal ini sesuai dengan $\mathrm{Wei}^{4}$ yang menyatakan bahwa pemberian kemoterapi dan radioterapi adalah pengobatan yang sesuai untuk KNF stadium II - IV.

Sedangkan menurut Brockstein and Vokes, ${ }^{11}$ pada kasus dengan metastasis, karsinoma berdiferensiasi buruk (undiferen tiated), atau limfo epitelioma pada nasofaring sangat sensitif terhadap kemoterapi.

Pada penelitian ini dilakukan pemeriksaan ekspresi NF $\kappa$ B dan c-myc pada KNF. Ini sesuai dengan Faumont et $\mathrm{al}^{9}$ dan Thompson ${ }^{16}$ yang menyatakan bahwa adanya ekspresi NFkB yang positif ini disebabkan oleh EBV pada KNF yang akan menyebabkan terjadinya ekspresi dari LMP1. Selanjutnya LMP 1 melalui mekanisme TNF (Tumor Necrosis Factor) bertanggung jawab atas terjadinya aktivasi dari NF- $\mathrm{kB}$ secara kontinyu. Hal ini menggambarkan bahwa pada KNF undifferentiated sangat berasosiasi kuat dengan infeksi EBV.

Murdani ${ }^{17}$ pada tahun 2009 juga melakukan penelitian mengenai peran NFאB dan COX-2 pada karsinoma kolorektal. Didapatkan adanya ekspresi positif NFKB sebesar 73,5\% dan ekspresi COX-2 sebesar 49,0\%. Hal ini menunjukkan bahwa pada malignansi akan terdapat peningkatan ekspresi dari NF-кB.

Adanya peningkatan ekspresi c-myc dalam proses malignansi, juga dikemukakan pada penelitian Prayitno dkk. ${ }^{18}$ Adanya ekspresi c-myc yang tinggi menunjukkan bahwa siklus sel sedang berlangsung, karena fungsi c-myc adalah sebagai protein pemicu terjadinya transkripsi sel.

Rahayu ${ }^{19}$ pada tahun 2008 di RS Dr Soetomo Surabaya juga meneliti mengenai ekspresi c-myc dan Bcl2 pada KNF jenis undifferentiated dan hubungannya dengan $T$-stage dan $N$-stage. Meskipun tidak didapatkan adanya hubungan antara ekspresi c-myc dan Bcl2 dengan T-stage dan $N$-stage, tetapi didapatkan adanya ekspresi c-myc 38.5\% dengan tingkat ekspresi +1 dan +3 . Pada penelitian ini dilakukan pemeriksaan NF$\kappa \mathrm{B}$ dan c-myc sebelum dan sesudah kemoterapi neoadjuvant. Diharapkan dengan pemberian terapi ini dapat menghambat proses keganasan yang terjadi, sehingga tingkat ekspresi NF- $\mathrm{BB}$ dan c-myc akan menurun.

Adanya peningkatan tingkat ekspresi NF$\kappa \mathrm{B}$ dan c-myc ini dimungkinkan karena adanya beberapa hal, yaitu responss terapi yang komplit tidak didapatkan, sehingga sebe narnya proses malignansi masih berlangsung. Hal ini sesuai dengan penelitian Sari, ${ }^{6}$ bahwa hasil evaluasi pasca kemoradioterapi pada 101 pasien KNF di Rumah Sakit Dr Moewardi Surakarta pada tahun 2009 yang mempunyai respons komplit hanya sebesar $4,95 \%$.

Respons komplit yang gagal didapatkan, bisa disebabkan radioterapi yang digunakan adalah 
radioterapi konvensional, bukan radioterapi hiperfraksinasi. Menurut Penelitian Dana dkk seperti yang dikutip dari Hariwiyanto, ${ }^{20}$ KNF yang diterapi dengan radioterapi konvensional yang mengalami respons komplit hanya $46 \%$, sedangkan dengan radioterapi hiperfraksinasi 73,3\% akan didapatkan respons komplit. Selain itu bisa juga karena angka kekambuhan pasca radioterapi yang masih cukup tinggi, yaitu antara $18 \%-45 \%$.

Adanya faktor resistensi terhadap obat kemoterapi juga bisa berperan dalam proses malignansi yang masih berlangsung . $^{411}$

Selain itu, $80 \%$ pasien dalam penelitian ini sudah pada stadium III dan IV dengan kemungkinan lebih besar sudah terjadi metastase, sehingga angka keberhasilan terapinya memang rendah. ${ }^{1,2,4}$ Menurut Lee seperti yang dikutip dari Hariwiyanto, ${ }^{20}$ apabila sudah terdapat metastase jauh, 85\% pasien KNF akan meninggal dalam tahun pertama. Five year survival rate karsinoma nasofaring stadium IV adalah sebesar 16,4\%. ${ }^{1}$

Kegagalan terapi KNF yang terbanyak menurut menurut penelitian Fandi et al pada tahun 2000 dan Farias et al pada tahun 2003 seperti yang dikutip dari Hariwiyanto, ${ }^{20}$ adalah terjadinya kekambuhan baik pada tumor primer maupun pada kelenjar limfe regional pasca radioterapi.

Selain itu ekspresi NF-кB dan c-myc yang masih tinggi pasca kemoterapi neoadjuvant berhubungan dengan pertahanan sel agar tetap dapat bertahan hidup sebagai respons dari stres yang dalam hal ini utamanya adalah kerusakan DNA karena radioterapi. ${ }^{12,14}$

Peningkatan ekspresi NFkB dan c-myc pasca kemoterapi neoadjuvant juga dapat disebabkan karena proses inflamasi dan proses proliferasi sel yang masih berlangsung setelah radioterapi. ${ }^{14}$

Pengambilan biopsi yang dilakukan 2 bulan sesudah radioterapi, ini sesuai dengan fase intermediate pasca radioterapi yang berlangsung antara 3 minggu sampai 6 bulan, fase saat terjadi proses inflamasi dan proliferasi jaringan akibat efek radioterapi. ${ }^{14}$
Pada radioterapi akan terjadi reaksi indirek yang merupakan proses interaksi radiasi pengion dengan sel tumor maligna dan timbulnya radikal bebas yang meningkatkan ekspresi NFкB sebagai pertahanan sel terhadap stres. ${ }^{9,14}$ Adanya radikal bebas dan proses inflamasi akibat pemberian radioterapi bisa merupakan faktor perancu yang bisa meningkatkan ekspresi $\mathrm{NF \kappa B}$ yang pada akhirnya juga akan meningkatkan ekspresi c-myc., ${ }^{9,13,14}$

Hasil analisis adanya hubungan antara ekspresi NFkB dengan ekspresi c-myc pada penelitian ini signifikan $(p=0.001)$. Hubungan ini cukup kuat, karena mampu dijelaskan sebesar $43,5 \%$, selebihnya sebesar $56,5 \%$ peningkatan ekspresi c-myc akibat faktor lain.

Ini sesuai dengan penelitian Faumont et $\mathrm{a}^{9}$ yang menyatakan bahwa pada proses malignansi, adanya peningkatan ekspresi c-myc disebabkan oleh peningkatan ekspresi NFkB.

Faktor lain yang tidak diperhitungkan dalam penelitian ini termasuk adanya ekspresi NFkB yang disebabkan adanya proses inflamasi dan reaksi jaringan akibat stres pada DNA, sebagai reaksi sesudah pemberian radioterapi. Ekspresi c-myc yang masih ada bisa disebabkan adanya proliferasi sesudah pemberian radioterapi. Hal ini sesuai dengan penelitian Gourin dan Terris. ${ }^{14}$

Pada penelitian ini didapati ekspresi $\mathrm{NF} \kappa \mathrm{B}$ dan c-myc sebelum dan sesudah kemoterapi neoadjuvant pada KNF jenis undifferentiated. Juga terdapat peningkatan ekspresi $\mathrm{NF \kappa B}$ dan c-myc sesudah pemberian kemoterapi neoadjuvant, yang bisa disebabkan karena progresivitas KNF, proses inflamasi maupun karena reaksi jaringan akibat stres pada DNA sebagai reaksi sesudah pemberian radioterapi. Didapatkan hubungan yang signifikan dan kuat antara ekspresi NF $\kappa \mathrm{B}$ dan c-myc pada karsinoma nasofaring jenis undifferentiated. Kami menganggap perlu dilakukan penelitian lebih lanjut dengan pemeriksaan biomolekuler lain seperti COX2, iNOS, MMP-9 sebagai penanda biomolekuler untuk tumor promotion, sehingga dapat diketahui apakah peningkatan ekspresi $\mathrm{NF} \kappa \mathrm{B}$ dan c-myc setelah kemoterapi neoadjuvant 
pada penelitian ini disebabkan adanya proses inflamasi atau karena progresifitas dari karsinoma nasofaring.

\section{DAFTAR PUSTAKA}

1. Roezin A, Syafril A. Karsinoma naso faring. Dalam Soepardi EA, Iskandar N, Bashirudin J, Restuti RD (Eds). Buku ajar ilmu kesehatan telinga hidung tenggorok kepala dan leher. ed. ke 5. Jakarta : Balai Penerbit FKUI; 2003. hal.146 - 50.

2. Tan IB. Treatment of nasopharyngeal carcinoma in Indonesia; Looking into the mirror. Makalah Kongres Nasional PERHATI-KL XV, Makasar; 2010.

3. Huang DP, Wailo. Aetiology factor and pathogenesis. In: Gibb VH, editor. Nasopharyngeal carcinoma. $2^{\text {nd }}$ ed. Hongkong: The Chinese University Press; 1999 p.31-51.

4. Wei IW. Nasopharyngeal cancer. In Calhoum KH, Healy GB, Jhonson JT, Jackler RK, Pilbury H, Trady ME editors. Bailey BJ Head and Neck Surgery - Ottolaryngology, $\quad 4^{\text {th }}$ ed. Philadelphia: Lippicot Wiliam \& Walkins; 2006 p.1650 - 72.

5. Chan TC, Teo PM. Nasopharyngeal carcinoma: review. Ann Oncol 2002; 13:1007-15.

6. Sari AK. Gambaran kejadian karsinoma nasofaring tahun 2007-2009 di RSUD Dr Moewardi Surakarta. Presentasi Karya Ilmiah Nasional, Surakarta: IK THT Fakultas Kedokteran UNS; 2010.

7. Nishikori M. Classical and alternative NF-kB activation pathways and their roles in lymphoid malignancies. J Clin.Exp. Hematopathol 2005; 45.

8. Bonizzi G, Bebien M, Otero DC, Johnson-Vroom KE, Cao Y, and Vu D. et al. Activation of IKKalpha target genes depends on recognition of specific kappaB binding sites by RelB:p52 dimers. J EMBO 2004; 23 (21):4202-10

9. Faumont N, Panteix SD, Schlee M, Gromminger S, Schuhmacher M, and Holzel M . et al. c-Myc and $\mathrm{Rel} / \mathrm{NF}-\mathrm{Kb}$ are two master trans criptional systems activated in latency III program of Epstein-Barr Virusimmor talized B cells. J Virol 2009; 83:5014-27.

10. You Z, Madrid VL, Saims D, Sedivy J, Wang
CY. c-myc sensitizes cell to tumor necrosis factormediated apoptosis by inhibiting nuclear factor $\kappa \mathrm{B}$ transactivation. J Biol Chemistry 2002; 277: 36671 7.

11. Brockstein EB, Vokes EE. Principles of chemotherapy in the management of head and neck cancer. In Calhoum KH, Healy GB, Jhonson JT, Jackler RK, Pilbury H, Trady ME, editors. Bailey B.J head and neck surgery-otolaryngology, $4^{\text {th }}$ ed. Philadelphia: Lippincot Wiliam \& Wilkins; 2006 p.1428-41.

12. Lica L, Rebecca F. Radiation therapy in Gale Encyclopedia of Medicine, $3^{\text {rd }}$ ed. Gale Research; 2006.

13. Tjokronagoro M. Biologi sel tumor maligna, Yogyakarta: Fakultas Kedokteran UGM; 2001.

14. Gourin, GC, Terris JD. Dynamic of wound healing. In Calhoum KH, Healy GB, Jhonson JT, Jackler RK, Pilbury H, Trady ME, editors. Bailey B.J head and neck surgery-otolaryngology, $4^{\text {th }}$ ed. Philadelphia: Lippincot Wiliam \& Wilkins; 2006 p. 1650 - 72.

15. Arief M. Pengantar Metodologi Penelitian untuk ilmu Kesehatan, ed 2, Klaten: CSGF the Community of Self Help Group Forum; 2004. hal.121- 33.

16. Thompson JE, Phillips RJ, Erdjument-Bromage H, Tempst, $\mathrm{P}$ and Ghosh $\mathrm{S}$. IkB- $\beta$ regulates the persistent response in a biphasic activation of NFk-B. J Cell 1995; 80:573-82

17. Murdani A. Peran NFkB dan COX-2 serta hubungan dengan Karakteristik klinikopatologis, Jakarta: Pusdalin IDI; 2009.

18. Prayitno A, Darmawan R, Yuliadi I, Mudigdo A. Ekspresi protein $p 53, R b$, dan $c-m y c$ pada kanker serviks uteri dengan pengecatan immuno histokimia. Biodiversitas 2005; 6:157- 9 .

19. Rahaju AN. Ekspresi c-myc dan Bcl 2 pada karsinoma nasofaring jenis undifferentiated, Surabaya: Departemen Patologi Anatomi FK Universitas Airlangga; 2009.

20. Hariwiyanto B. Peran EBNA-1, EBNA2, LMP-1 dan LMP-2 virus Epstein-Barr sebagai faktor prognosis dalam pengobatan karsinoma nasofaring. Yogyakarta: Fakultas Kedokteran Universitas Gajah Mada; 2009 